\title{
MAgÁNISKOLÁK A TANÜGYIRÁNYÍTÁS VÁLTOZÓ RENDSZERÉBEN
}

\author{
SZEGEDI ESZTER
}

A tanulmány központi kérdése, hogy vannak-e lényeges változások a magán oktatási intézmények müködésére nézve a 2010 utáni centralizáció következményeként a rendszerváltáskor kialakult szabályozási feltételekhez képest. A tanulmány feltárja az iskolaalapításra és müködtetésre vontakozó szabályozás változásának lényegi elemeit, a magániskolák oktatási rendszeren belüli arányának alakulását húsz éves időtávon, valamint a vonatkozó finanszírozási és ellenőrzési rendszert, különös tekintettel a magánszakképzés visszaszorulását okozó közvetett szabályozási eszközökre.

Kulcsszavak: magániskolák, tanügyirányítás, tanszabadság, szakmaszerkezeti döntés

The central question of the study is whether there are any significant changes in the functioning of private educational institutions as a consequence of the centralizing measures after 2010, compared to the regulatory conditions at the Hungarian system change. The study explores the essential elements of the change in the regulation of the foundation and operation of schools, the trends of the proportion of private schools within the education system through the past 20 years, and the relevant funding and control system, with particular reference to indirect regulatory instruments, led to a reduction of private schools in vocational education.

Keywordsः private schools, regulatory changes in Hungary

\section{Bevezetés}

anulmányom központi kérdése, hogy vannak-e lényeges változások a magán oktatási intézmények működésére nézve a 2010 utáni centralizáció következményeként a rendszerváltás után kialakult szabályozási feltételekhez képest. Fő forrásai a jogszabályok elemzése, a magániskolákról elérhető aránylag szűk szakirodalom áttekintése, a szektor képviselőivel készült interjúk mint háttérinformációk, és saját intézményvezetői tapasztalatom.

Levelező szerző: Szegedi Eszter. E-mail: szegedi.eszter@gmail.com 
$\mathrm{A} z$ alapítványi és magániskolák a rendszerváltás idején indultak el, szerepük több társadalmi csoport számára is meghatározó. Sok köztük a hagyományos reformpedagógiát képviselő vagy reformpedagógiai gyökerű modern alternatív iskola. Ezek többségét olyan törekvések hívták életre, melyek kapcsán egymásra találtak a gyermekük jövőjéről és iskoláztatásáról tudatosan gondolkodó, erős érdekképviseletű társadalmi csoportok és a pedagógiai megújulást és szabadságot kereső - többnyire fiatal - tanárok. Másik fontos szegmens a hátránykompenzáló iskolák köre, amelyek a hátrányos helyzetű és magukra hagyott tanulói rétegek felkarolását tűzték ki célul, a kudarcos tanulási pályájú fiatalok civil szervezeteken keresztüli támogatását és visszavezetését az oktatásba és/ vagy a munkába egyszerre. A harmadik nagy csoport pedig az üzleti célú (elsősorban szakképző) intézmények, melyek többek között képzési kínálatukban is vevőközpontú logikában kezdtek el müködni és egyszerre választ adni a munkaerőpiaci és a fogyasztói keresletre.

A magániskolák kezdettől fogva népszerüek voltak a szülők egy körében, mára pedig a jelenlegi intézményi kapacitásokat meghaladó túljelentkezés jellemző. Kezdetben a versenyelőnyt a barátságos, szabad légkör, az együttműködő tanár-diák kapcsolat, a személyközpontú módszerek, az egyéni és csoportos differenciált foglalkozások jelentették (Vágó 2005), mostanra azonban inkább a kialakult presztízs számít. Az alternatív és magániskolák pedagógusai jelentős arányban részt vettek az elmúlt évtizedek szakmai fejlesztéseiben és fejlesztéspolitikai projektjeiben, így az iskolák keretein belül elindított modernizáció visszahatott a központi tartalmi szabályozókra, a tankönyvpiacra és a továbbképzésekre is.

A kezdeti magányos harcos utakhoz képest a magániskolák egy része mostanra már együttmüködő hálózatokba szerveződött. Két nagy érdekeképviseleti szervezet és a hozzájuk kapcsolódó pedagógiai szolgáltató központ ${ }^{1}$ támogatja az intézményeket, melyek nagyon fontos kontrollszerepet töltenek be a döntéshozatali és szabályozási folyamatban is, mindemellett segítik a tagintézmények napi működését, elsősorban a tanügyigazgatási változások követésében.

Érdemes megvizsgálni, hogy hogyan hatottak az elmúlt tíz év átalakítási folyamatai az oktatási rendszer ezen izgalmas szegmensére. A magániskolák jelenlegi helyzetének és szerepének elemzése nem nélkülözheti a téma mélyebb megértését szolgáló kitekintést a rendszerváltás utáni évek során érvényesített oktatáspolitikai vívmányokra és az azóta lezajlott számos további reformkísérlet mozgatórugóira; valamint aligha értelmezhető a közigazgatás és a szabályozási környezet más területein (pl. egyházügyi törvény) az elmúlt tíz évben lezajlott jelentős változások ismerete nélkül. Tanulmányomban a hangsúly ugyan a 2010 utáni változások hatásán van, de ahol az segíti a megértést, ott nemcsak a magániskolákra vonatkozó, hanem a tágabb szabályozási környezet alakulásának előzményeit is bemutatom.

Nagyobb érdekképviseleti szervezetek: Alapítványi és Magániskolák Egyesülte és Magyar Waldorf Szövetség; pedagógiai szolgáltatók: Független Pedagógiai Intézet és Waldorf-ház. 


\section{Tanügyirányítási látlelet}

\section{Tanszabadság, iskolaalapitás és tartalmi szabályozás}

A 2011. évi CXC. törvény a nemzeti köznevelésről a magán közoktatási intézmény fogalmát a következőképpen határozza meg:

„4. $\$ 16$. magán köznevelési intézmény: a 2. $\S(3)$ bekezdés b) pont bc) és bd) alpontjában meghatározott személy által fenntartott köznevelési intézmény."

Azaz magánfenntartó lehet vallási egyesület vagy más személy vagy szervezet (ez utóbbi alá tartozik bármely más jogi forma: alapítvány, egyesület, felsőoktatási intézmény, magánszemély vagy vállalkozás stb.). E törvény értelmében köznevelési intézmény fenntartására szinte mindenkinek joga van, kivéve a korábbi legnagyobb arányú fenntartót, a helyi önkormányzatokat. ${ }^{2}$ Ennek jelentősége csak a rendszerváltás idején zajló szabályozási reformtörekvésekre való visszatekintéssel érthető meg.

Az iskolai innovációk, kísérleti programok elindulásának feltételeit az 1985-ös oktatási törvény tette először lehetővé, az egyházi és magániskolák újraindulásának jogi feltételeit pedig a rendszerváltás után módosított szabályozási környezet teremtette meg. A deklarált szabadságjogok törvényi kereteinek kidolgozása több évig tartott. $\mathrm{A} z$ 1989-es alaptörvényben lett rögzítve a tanszabadság és a tanítás szabadságának alapelve, továbbá ebben deklarálták a vallás szabadságát, valamint az anyanyelvű oktatáshoz való hozzáférés jogát a nemzetiségek számára. 1993-ban készült el az oktatási rendszer új szabályozását leíró törvény, melyben a tanszabadság részletei is kidolgozásra kerültek. Ez rögzíti, hogy a közoktatás rendszerének müködtetése az állam feladata, a közoktatás nevelési intézményei szakmailag önállóak, óvodát, iskolát, kollégiumot, pedagógiai szakszolgálatot, valamint pedagógiai-szakmai szolgáltatást ellátó intézményt az állam, a helyi önkormányzat, a kisebbségi önkormányzat, egyházi jogi személy, gazdálkodó szervezet, alapítvány, egyesület és más jogi személy, továbbá természetes személy alapíthat és tarthat fenn. A törvény explicit módon jeleníti meg a szektorsemlegesség elvét és a szabad iskolaválaszztás jogát is.

A 2011-ben újra módosított alkotmány a tanítás szabadságát a szövegben tett kis módosítással törvényben meghatározott keretekhez köti. Ezzel egyidejűleg a 2011-es új köznevelési törvényben már nem kerül említésre a szektorsemlegesség és a szabad iskolaválasztás joga. Mindez együtt azt is jelenthetné, hogy a tanszabadság már alapelvként érvényesül a törvényben, ugyanakkor a szabályozási gyakorlat és az alaptörvény általános megfogalmazásai tág teret hagynak az értelmezésre. 2011-ben újraírták az oktatási rendszer szabályozásának alapdokumentumait (köznevelési és szakképzési törvény), és a rendszer egészére nézve több lépésben jelentős változtatásokat vezettek be, melyek legitimálására szintén törvénymódosítások formájában került sor (2013: az önkormányzati iskolák állami fenntartásba vétele; 2015: az önkormányzatok müködtetési jogának megvonása, valamint a szakképzési intézményrendszer átalakítása).

Fentiek tükrében érdemes vizsgálni, hogy az iskolaalapításra vonatkozó szabályozás hogyan változott az elmúlt években. A feltételeket a köznevelési törvény rögzíti, melyek az adminisztratív teendőket is beleértve lényegében a kilencvenes évek óta változatla-

A települési önkormányzatok a 2013-as törvénymódosítás óta csak óvodákat tarthatnak fenn, 2015-ben pedig az iskolaműködtetési jogukat is megvonták. 
nok és rendkívül tág teret hagynak az alapítók szakmai elképzeléseinek. Az 1995-ben megjelent első Nemzeti alaptanterv (továbbiakban NAT) és az azt kiegészítő, az iskolák által kidolgozandó helyi tantervek és pedagógiai programok szakaszosan kerültek bevezetésre, kialakítva a korábban itthon nem jellemző kétpólusú, majd a kerettantervekkel együtt hárompólusúvá váló tartalmi szabályozást. Ebben az időszakban számos kísérleti program is benyújtásra került, amire több oktatási szakértő is úgy emlékszik vissza, hogy „a pedagógiai szakemberek elképzelései jelentősen eltértek a realitástól”, mivel a sokféle elképzelést a hozzájuk rendelt eszközök hiányában nem lehetett használni (Knausz 2018). A kétezres évek elejére azonban kiépült az eszközrendszer is (alternatív kerettantervek, tankönyvek, módszertani segédletek és útmutatók), melyek egy része a fejlesztési programokhoz (pl. kompetenciaalapú oktatási csomagok), egy másik része a tankönyvpiac bővülésével együtt a tankönykínálathoz, harmadik részük pedig a különböző pedagógiai reformtörekvésekhez kötődött.

$\mathrm{A} z$ iskolákat felkészületlenül érte a szakmai önállóságnak ez a foka, ezért leggyakrabban a központi ajánlásokat vezették be helyi programként, melyekhez idővel a tankönyvkiadók is igazodtak. Noha a NAT 2003-ban és 2007-ben is felülvizsgálatra került, egyik változás sem volt olyan mértékü, mint a 2012-es módosítás, mely beemelte a tantárgyakat és a lexikális tudáselemeket, a tananyag felépítését és felosztását, illetve a tankönyvek tartalmát is meghatározta, konkrétabbá és egységesebbé kívánva tenni az oktatási tartalmakat a korábbi általános tudáselemek helyett. Ezzel együtt miniszteri engedélyhez kötötték az alternatív oktatási kerettantervek használatát, így azokat ismét be kellett nyújtani. A magánszektor megkérdezett képviselői nem tudnak olyan esetről, hogy ezek elfogadásában korlátozó elvek érvényesültek volna, a jelenleg elfogadott alternatív kerettantervek nagy része - bár számos módosítás ekkor került be a korábbi programokba - már 2012 elött is létezett, ${ }^{3}$ miközben a tankönykiadók kerettantervei eltüntek a kínálatból.

$\mathrm{A} z$ alternatív iskolai kerettantervekben meghatározható, az általános szabályoktól eltérő, sajátos müködési formák lényegében bármely oktatásszervezési, tartalmi és infrastrukturális eltérést lehetővé tesznek az alternatív utak keresői számára (a szabadságfokok közé tartozik pl. a tananyag és az értékelés módjának megválasztása, a heti óraszám, a pedagógusok munkaideje, a minőségpolitika rendszere, a vezetési modell stb.) [Nkt. 9. § (8)].

A szabályozási környezetben a nem állami (egyházi és magán-) fenntartású intézményekre általában azonos kitételek érvényesek, a rendszer egészében pedig közös szabályozási keret érvényesül. Így azonosak az ellenőrzésre, a szakmai szolgáltatások igénybevételére, az adatszolgáltatásra stb. vonatkozó feltételek és hivatalos szervek mindhárom szektor esetében. Összességében úgy tűnik, hogy az alternatív oktatás meghatározó tartalmi dokumentumai beépültek a közoktatás rendszerébe, a rendszerváltás utáni kezdeti sokszínűséget és minőségi egyenetlenséget a rendszer oldaláról a szakmai minőségi

\footnotetext{
3 A legtöbb iskola által használt alternatív kerettantervek között szerepel a Waldorf-kerettanterv, a Rogers-féle szociális kompetenciák fejlesztésére épülő alternatív alapfokú kerettanterv, a Zsolnai-féle Értékközvetítő és képességfejlesztő program. Néhány - több évtizedes múltú - iskola is rendelkezik saját kerettantervvel (Alternatív Közgazdasági Gimnázium, Közgazdasági Politechnikum, Novus Gimnázium, Kürt Alapítvány), illetve idetartoznak a hátránykompenzációra szakosodott intézmények is (Zöld Kakas Líceum, Belvárosi Tanoda).
} 
követelmények határozottabb érvényesítése váltotta fel, a magánoktatás képviselői pedig kialakították saját stabil szakmai bázisaikat.

A 2010 utáni - fent említett jelentős - törvényváltozások a rendszerváltás vívmányait a magánintézmények vonatkozásában jelen tanulmány írásáig gyakorlatilag nem érintik, az iskolaalapítás és -müködtetés feltételeinek szabályozása lényegében változatlan. A nyomdába adás előtti hetekben, 2019 nyarán zajlik azonban a köznevelési törvény újabb módosítása, mely erősen korlátozó hatású lehet az alternatív és magániskolák számára is, erős tiltakozást váltva ki érdekképviseleti szervezeteikből. Alig néhány hónappal azt követően, hogy az oktatási szaktárca engedélyezte a Budapest School magániskola Nemzeti alaptantervtől jelentősen eltérő saját kerettantervét, néhány hét alatt elfogadásra került egy olyan törvénymódosítás, mely érinti az alternatív kerettanterveket is (az intézményvezetők kinevezése, a magántanulói jogviszony, az óvodába járás és a tankönyvellátás szabályozása mellett). E törvényváltozás alapján a továbbiakban az alternatív kerettantervekben tanévenként két félévre bontva meg kell jeleníteni a NAT-ban meghatározott tananyagtartalmakat, valamint az alternatív kerettanterv tantárgyi struktúrája csak legfeljebb harminc százalékban térhet el az oktatásért felelős miniszter által kiadott kerettantervben foglalttól. A törvény végrehajtása annak hatályba lépésekor még szakmai értelmezési kérdéseket is felvet amellett, hogy tanügyirányítási szempontból egyértelműen korlátozó törekvés.

\section{A magániskolák aránya a közoktatásban}

A kilencvenes évektől élő szabad iskolaalapítási lehetőség újult lendületet adott a különböző alternatív és reformpedagógiai törekvések híveinek. A korábbi korlátozó keretekből kitörni vágyó pedagógusok és a gyermekeik számára tudatosan alternatív iskolát választó, jellemzően a középosztály felső rétegéből kikerülő szülői csoportok hamar egymásra találtak, és néhány év alatt számos - legtöbb esetben ma is müködő - magániskola került megalapításra. Az alapítók többnyire saját szabadságvágyuk és pedagógiai hitvallásuk szerint kezdték el müködtetni az intézményeket, melyhez az akkori keretek lényegében korlátlan autonómiát biztosítottak. Szintén elindult az államosított egyházi oktatási intézmények visszavétele.

2012-ig - amikor érvénybe lépett az önkormányzati iskolák állami fenntartásba vétele - viszonylag stabil arányok alakultak ki a különböző fenntartású intézmények megoszlásában. A EUROSTAT adatai alapján szerkesztett 1. ábra diagramjai jól szemléltetik, hogy noha a demográfiai csökkenés nagy arányú volt az elmúlt húsz évben (az iskolás korosztályokban 15-25\%), ez elsősorban az állami iskolák tanulói létszámára hatott, a nem állami fenntartású intézményekben (ebbe az egyházi iskolák is beletartoznak) folyamatosan nőtt a tanulói létszám. Legnagyobb arányban a szakképzésben jöttek létre magániskolák, ahol a leginkább müködtek a piaci mechanizmusok. Az ábrán jól látszik, hogy a nem állami iskolák aránya folyamatos növekedést mutat mindhárom iskolatípusban, kivéve az érettségi utáni szakképzést nyújtó iskolákat, amelyek aránya 2015 után jelentősen visszaesett.

Az Oktatáskutató és Fejlesztő Intézet által kifejlesztett EDUMAP adatai alapján a nem állami fenntartású intézmények arányait külön is vizsgálhatjuk. A 2. és 3. ábra jól mutatja, hogy lényeges változások az állami, egyházi és magánintézmények arányában 2010 után következtek be. 


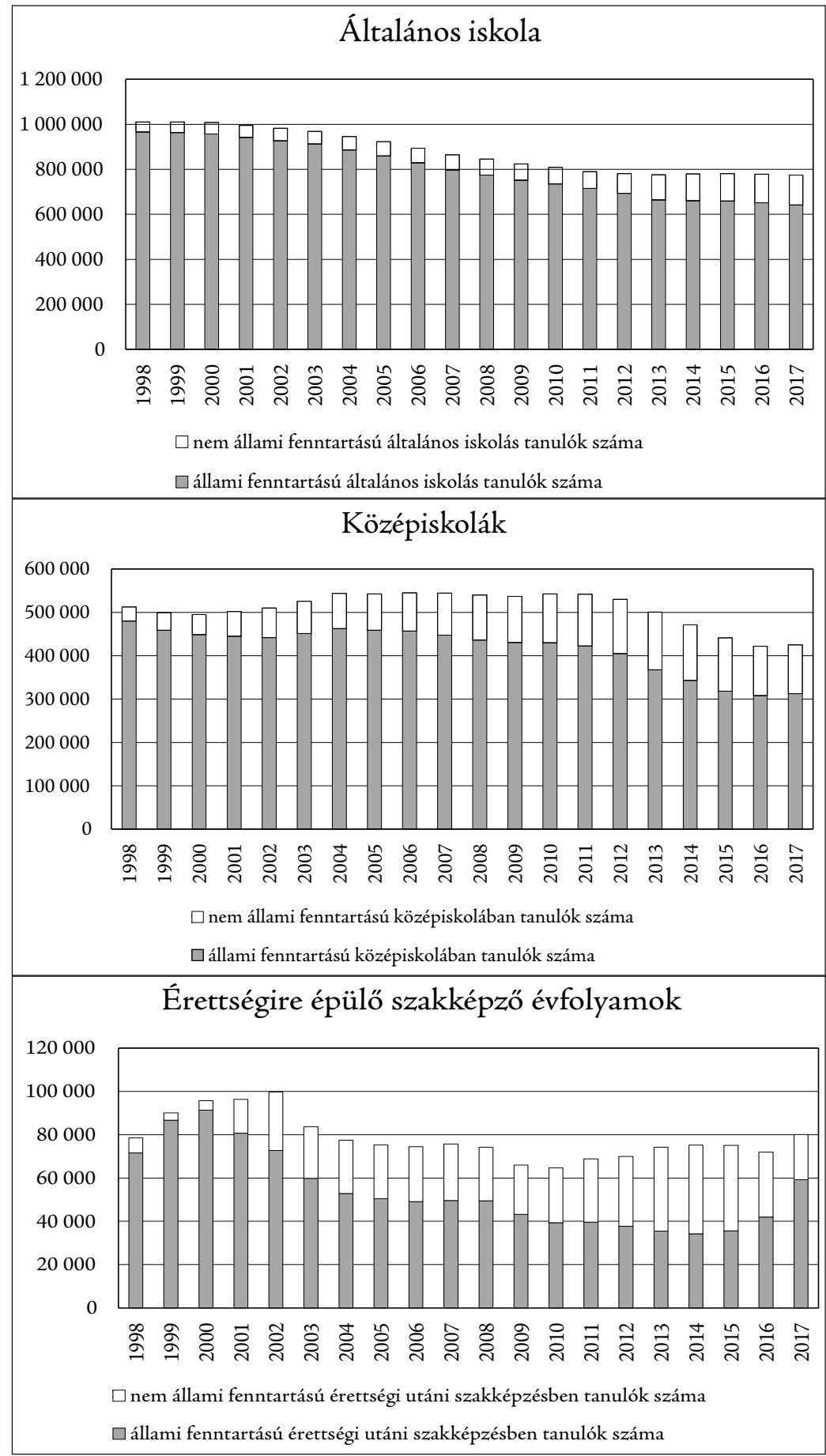

1. ábra: Az állami és nem állami fenntartású iskolákban tanulók száma, 1998-2017. Forrás: EUROSTAT [educ_enrl1at] és [educ_uoe_enra01], 2017 (saját szerkesztés) 


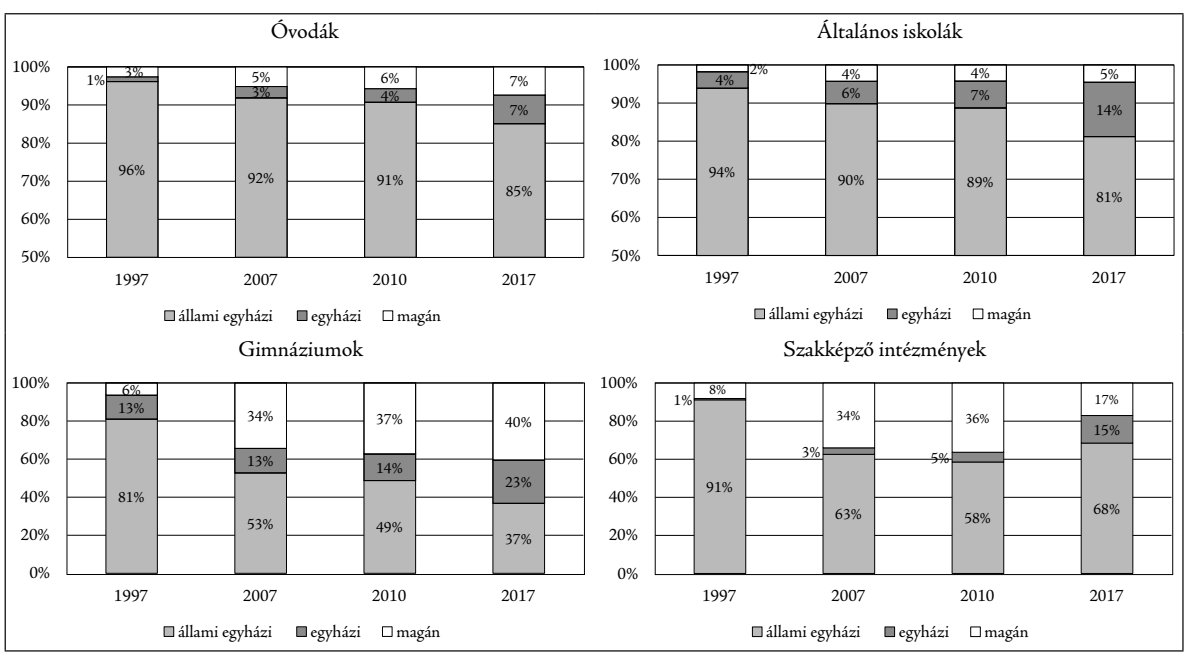

2. ábra: A feladatellátási helyek számának megoszlása fenntartó szerint, 1997-2017. Forrás:

Halász-Lannert 2000; KSH Stadat 2.6 Oktatás és EDUMAP, 2017 (saját szerkesztés)

$\mathrm{A} z$ óvodák esetében az utóbbi években jelentősen nőtt az egyházi fenntartású intézmények száma. 2012-ben ugrásszerűen nőtt meg a két alföldi régióban és KözépMagyarországon, jelentős mértékben, de a korábbi trendbe simulva Borsod-AbaújZemplén megyében. A magánfenntartású óvodák száma ezzel szemben csak Budapesten és Pest megyében változott jelentősen, ahol az elmúlt tíz évben nagyjából egyenletes ütemben kétszeresére nőtt az intézmények száma.

$\mathrm{A} z$ általános iskolák esetében az ezredforduló körül alakult ki egy viszonylag stabil arány a különböző fenntartótípusok között. A magániskoláknál ez azóta sem vátozott sokat, az összes intézmény 4-5\%-át teszik ki, de csak a tanulók 2\%-a jár ilyen intézménybe.

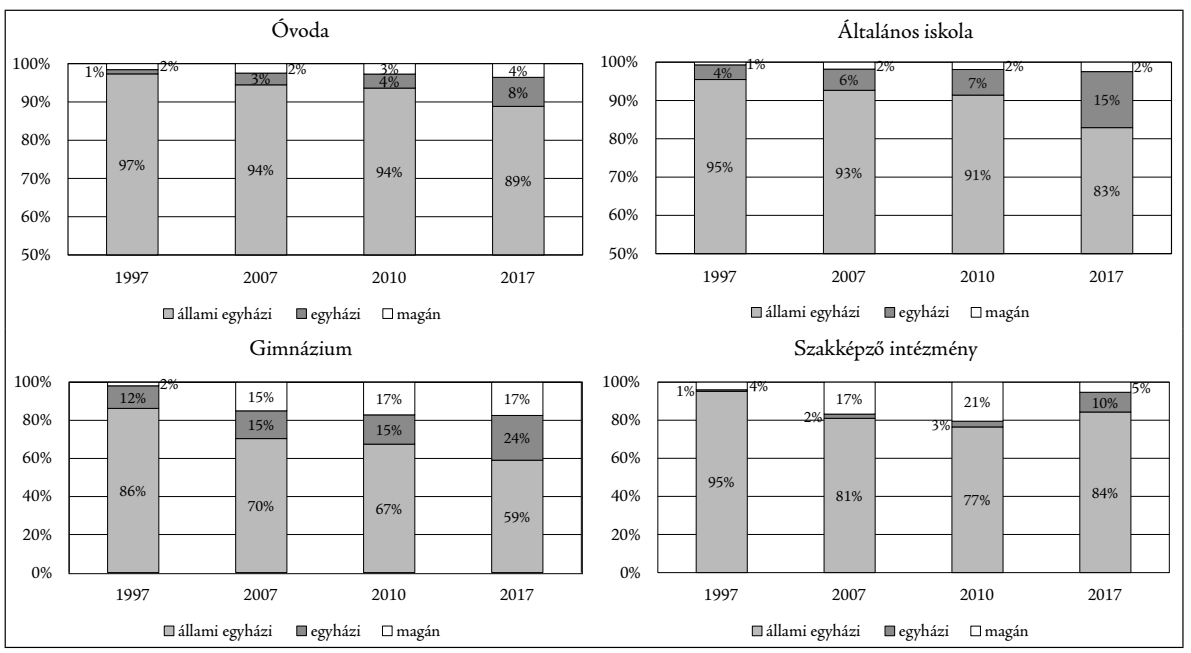

3. ábra: Tanulói létszámadatok megoszlásának változása fenntartó szerint, 1997-2017. Forrás: Halász-Lannert 2000, KSH Stadat 2.6 Oktatás és EDUMAP, 2017 (saját szerkesztés) 
Az egyházi fenntartású általános iskolák és az ott tanulók aránya ezzel szemben duplájára nőtt 2010 után (mind intézményi, mind a tanulói arány a korábbi 6-7\%-ról 14-15\%-ra nőtt).

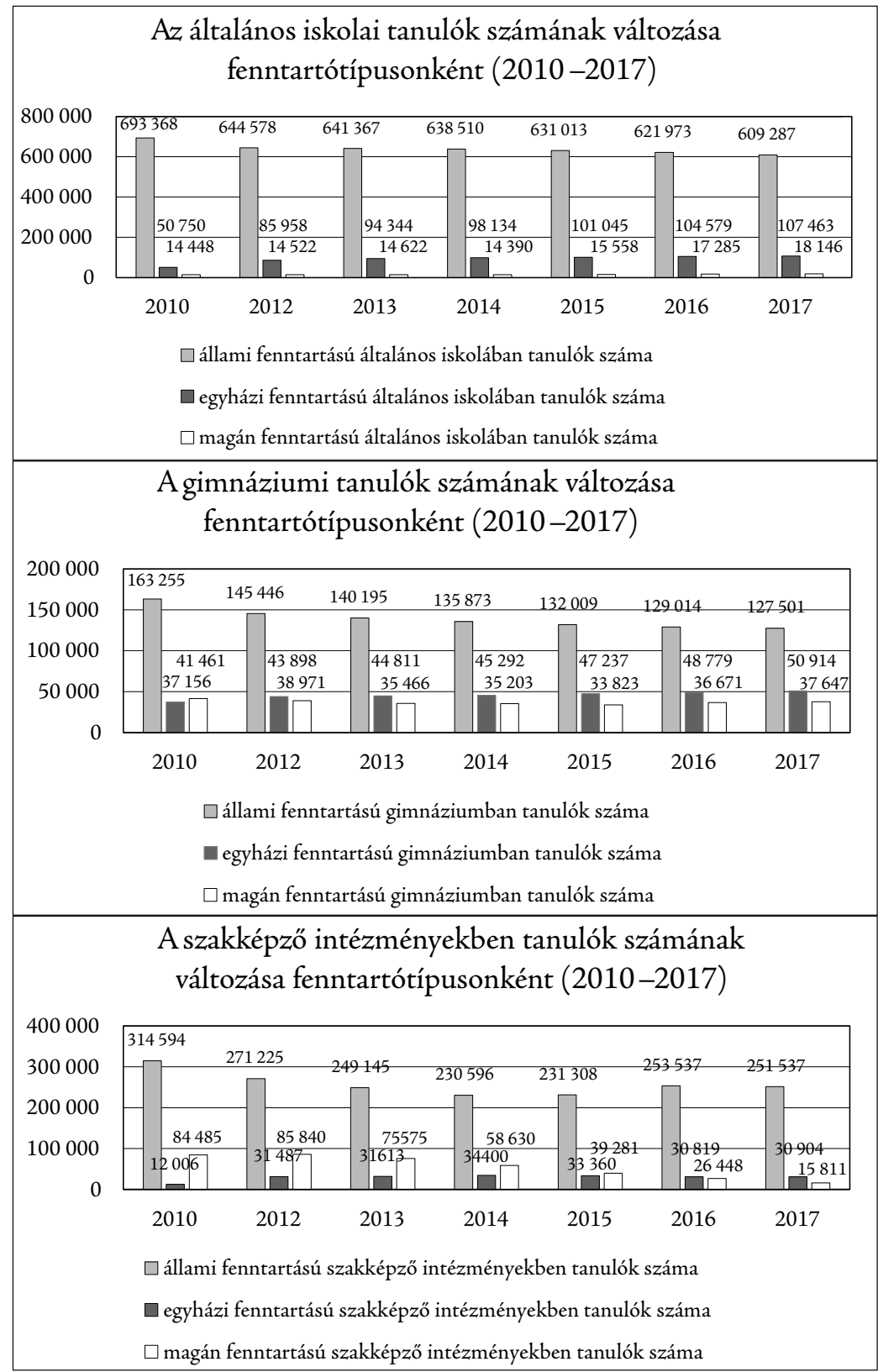

4. ábra: A tanulók számának változása képzési forma és fenntartótípus szerint. Forrás: EDUMAP, 2017 (saját szerkesztés) 
A nem állami fenntartású gimnáziumok már 2010 elött is az összes intézmény felét tették ki, bár ez a tanulói arányban csak valamivel több mint 30\%-ot jelentett. Az állam fenntartóként való 2012-es belépése a közoktatásba azonban újabb strukturális átrendeződést vont maga után. A 2017-ben érvényes arányok az egyházi intézmények esetében: intézmények és tanulók aránya az összeshez képest: 23\% és $24 \%$ a korábbi $14 \%$ és $15 \%$ kal szemben; míg a magánfenntartású gimnáziumok esetében a növekedés mérsékeltebb volt: 2017-ben az intézmények aránya 40\%, a tanulóké 17\%, mely évek óta változatlan. Azt lehet látni, hogy a diáklétszám csökkenése lényegében csak az állami gimnáziumokat érintette, az egyházi iskolákban jelentős növekedés történt, a magánintézmények száma pedig változatlan tanulói létszám mellett is nőtt.

Az összes képzési forma közül a szakképzést érintette legnagyobb mértékben az állami beavatkozás, és jelentős változásokat okozott a negyed század alatt kialakult képzési szerkezetben. 2012 után a magánfenntartású szakképző intézmények száma drasztikusan visszaesett: az iskolák arányában felére, a tanulói létszámot tekintve pedig negyedére. A legutóbbi időszak fenntartók szerinti tanulói létszámváltozásait mutatja be a 4. ábra. ${ }^{4}$

A magániskolák területi megoszlását tekintve nagy egyenlőtlenség mutatkozik. Budapesten és Pest megyében található az intézmények $\mathrm{kb}$. fele (az óvodákkal együtt 351, illetve 147 intézmény), a tanulói létszám ezzel szemben csak kb. 30\%-a a teljes beiskolázotti körnek. Szabolcs-Szatmár-Bereg megyét leszámítva (136 intézmény), a többi megyében alig néhány tucat magánfenntartású közoktatási intézmény van. $\mathrm{A} z$ országos átlag $10 \%$, szemben az egyházi intézmények $12 \%$-os arányával, és a tanulói létszám jellemzően kisebb (összesen 5\%). A hátrányos és halmozottan hátrányos helyzetű diákok a magániskolákban alulreprezentáltak az országos átlaghoz képest.

\section{Finanszírozás és ellenőrzés a közoktatásban müködő magániskoláknál}

\section{Nemzetközi összehasonlitás}

Az OECD Education at a Glance (EAG) kötetei éves összehasonlításban mutatják a tagállamok fontosabb oktatási indikátorait, köztük az oktatás finanszírozási mutatóit is. A különböző társadalmi alrendszerekre - köztük az oktatásra - vonatkozó költségvetési döntésekben nagy szerepet játszik, hogy az adott ország milyen prioritást szán az adott ágazatnak, és milyen mértékben támaszkodik vagy engedi be a magánszolgáltatókat a területre. A kormányzati finanszírozás olyan helyzetekben szükséges, amikor a közhasznúság magas, de a magánköltségek nagyobbak, mint a privát elönyök. Az oktatás hagyományosan olyan terület, ahol a kormányok hozzátesznek a magánszolgáltatások nyújtásának finanszírozásához. Különböző nemzetközi modellek léteznek, a magániskolák állami iskolákéval azonos finanszírozásától (Németország, Hollandia) a nagy presztizsű és arányú magániskolai rendszerig, amelyben a szolgáltatás költségeit jellemzően a szülők viselik (angolszász országok). Eltérő az országokban az is, hogy a

\footnotetext{
A 2-4. ábra szakképzési intézményei között nem szerepelnek a (speciális) szakiskolák, mivel azok száma a többihez viszonyítva nagyon alacsony, az összehasonlítást ez nem befolyásolja. A 200 készségfejlesztő szakiskolából mindössze 10 van magánfenntartásban és 12 egyháziban. Noha az összes iskola száma 35\%kal nőtt az elmúlt 10 év alatt, a tanulói létszám 25\%-kal csökkent (2017-ben 7187 tanuló, ebből a magánintézmények a 2010-es 445 diákhoz képest 2017-ben már csak 289 diákot iskoláztak be).
} 
kormányzat a finanszírozásért cserébe milyen mértékben kíván beleszólni az iskolák irányításába és ellenőrzésébe (EAG 2018).

Érdemes megjegyezni, hogy az esélyegyenlőség terén jól teljesítő országok esetében a közoktatásban a privát források aránya jellemzően alacsony, vagyis az állami szerepvállalás tudatosabb ezen a téren. A tisztán piaci logika nem biztosítja az egyenlő hozzáférést az oktatási lehetőségekhez és a minőséghez, ezért fontos az állam szerepvállalása annak érdekében, hogy ne tolódjon el az egyensúly a privilegizált társadalmi csoportok érdekei mentén.

$\mathrm{Az}$ OECD-országokban a magánszektor hozzájárulása az oktatási célú kiadásokhoz átlagosan 13\%. A 2015-ös adatok szerint ez az arány Magyarországon is hasonló, 14\% - szemben a 2005-ös 9\%-kal -, de nem egyenlően oszlik meg a köznevelés (óvodától a középfokú oktatásig: 7\%) és a felsőoktatás (37\%) között (EAG 2018: 278).

\section{A magániskolák hazai finanszírozása}

Magyarországon már a rendszerváltás előtt is léteztek olyan, ún. elit iskolák, melyek a társadalmilag erős érdekképviselettel rendelkező csoportok igényeit szolgálták ki. A szabad iskolaválasztás és a szerkezetváltó iskolák megjelenésének lehetősége tovább növelte a felső középosztály lehetőségeit, ami kialakította a versenyt - elsősorban - a gimnáziumok között, vagyis az állami, és nem a magániskolák között lett erőteljesebb a verseny.

Saját iskolák alapításával a tanszabadság megnyíló lehetőségét hamar megragadták az alternatív oktatási programban gondolkodó szülők, illetve a saját rendszerű elitképzést megteremteni szándékozó, jellemzően céges támogatottságú érdekcsoportok (Dobos 2017). A korábban említett, a reformokat rögzítő 1993-as közoktatási törvény 1996. évi módosítása teremtette meg a magánoktatás finanszírozási feltételeit. Eszerint az állam gondoskodik az ingyenes és kötelező általános oktatásról, ideértve a helyi önkormányzati feladatellátás finanszírozásának biztosítását is. A törvény értelmében a nem állami, nem önkormányzati iskolák fenntartói számára biztosított központi normatív támogatás összege nem lehet kevesebb, mint az önkormányzatok számára biztosított támogatás, vagyis a támogatásban is érvényesül a szektorsemlegesség elve. További lehetőséget jelentett, ha a magán iskolafenntartók a helyi önkormányzattal vagy a művelödési tárcával közfeladatok ellátására vonatkozó külön megállapodást kötöttek, mivel ekkor a normatív támogatás mellett a központi vagy helyi költségvetésből kiegészítő támogatást is kaphattak.

Az 1997-ben megkötött vatikáni szerződés (majd annak több egyházra való kiterjesztése) garantálta mind az államosított vagyon egy részének visszaadását, mind az azok egy részében újra működni kezdő intézményrendszer állami támogatását, vagyis az egyházi iskolák már ekkor különleges státusszal bírtak.

A magánintézmények finanszírozása a közoktatásban viszonylag stabil konstrukció szerint zajlott az elmúlt harminc évben. A már említett normatív támogatást különböző céltámogatások egészítették ki, melyekre az önkormányzati intézményekkel azonos feltételek mellett voltak jogosultak. A magániskolák nagy része szakmai és anyagi függetlenségük biztosítása érdekében egyesületi vagy alapítványi formában kezdte meg müködését, melyen keresztül a fenntartó civil szervezet a családoktól kért támogatással egészítette ki a központi normatívát. Számos esetben az önkormányzattal ápolt jó kapcsolatok révén még helyi szinten is tudtak támogatáshoz jutni. A legnagyobb nehézséget 
számukra mindig az infrastrukturális feltételek megteremtése jelentette. Kevés olyan szerencsés iskola volt, amely egy-egy nagyobb befektetőnek vagy az együttműködő önkormányzatnak köszönhetően saját épületre tudott szert tenni, ezért a legtöbb magániskola számára ez folyamatos gondot okozott. A 20-25 év alatt nagyméretűre nőtt iskolák esetében jelenleg is ez jelenti a legnagyobb kihívást: komoly infrastruktúrát kell fenntartani piaci bérleti díjszabás mellett, ezért gyakori, hogy saját építkezésbe kezdenek, mely komoly terhet ró a fenntartó szervezetre és az azt támogató (többnyire) szülöi körre.

A finanszírozási logikában jelentős változást csak a 2011-12-es finanszírozási struktúra átalakítása jelentett, amikor a normatív támogatás helyett áttértek az átlagbéralapú támogatásra. Az önkormányzati iskolák állami fenntartásba vétele óta nehezen követhető azok finanszírozása, így a magániskolák helyzetét a velük együtt szabályozott nemzetiségi önkormányzati és egyházi iskolákkal vethetjük össze. Az átlagbéralapú támogatás esetükben azonos, a másik kettő azonban további kiegészítő müködési támogatásra is jogosult. ${ }^{5}$

Nem nyilvánvaló annak a kérdésnek a megválaszolása, hogy értelmezhető-e jogi diszkriminációnak az alapítványi és magániskolákkal szemben, hogy az egyházi és nemzetiségi iskolák további kiegészítő támogatásra is jogosultak. Utóbbiak jellemzően nem kérnek tandíjat vagy más jogcímen szülői hozzájárulást, míg a magániskolák nagy része igen. ${ }^{6} \mathrm{~A} z$ átlagbéralapú finanszírozás - mivel számítási alapját a tanulói létszám jelenti - a magasabb tanulói létszámmal müködő magániskolákat a korábbinál kedvezőbb helyzetbe hozta, a kisebb iskolák számára azonban nehézséget jelent. A NAT bevezetése és a kerettantervek megjelenése az abban meghatározott kötelező óraszámok alapján egyre pontosabb tervezési lehetőséget kínált a központi irányítás számára a pedagógusok szükséges létszámának kalkulálására, így alakulhatott ki a normatív logikáról egyfajta bértömeg-gazdálkodásra való áttérés. Az alapvető dilemmát az jelenti, hogy a finanszírozás és a tanszabadság eltérő logikát diktál, mivel az állami kerettantervek által számolt átlagok nem feltétlenül azonosak az állam által szintén elfogadott alternatív képzési programok finanszírozási igényeivel. Vagyis a szektorsemlegesnek látszó finanszírozás csak az egyházi és nemzetiségi iskolák vonatkozásában veszi figyelembe a képzési programokat, az esetlegesen nagyobb tanár- és eszközigényt.

A magániskolákban a tankerületi központokhoz tartozó iskolákhoz képest jóval szabadabbak a gazdálkodás feltételei, lehetőség van a bérek differenciálására (habár a központi elöírásokat a minimum szint erejéig alkalmazni kell), valamint a magániskolák pedagógusaira 2013 januárjától azonos módon érvényesek a életpályamodell törvényi keretei.

Hasonlóan azonos módon jogosultak az étkeztetési és a tankönyvtámogatásra is. 2019-re azonban a tanönyvtámogatást szinte csak a minisztériumi háttérintézet által kifejlesztett új tankönyvekre lehet költeni, így a tankönyv megválasztásában szabadságot

Ez lényegében a vatikáni szerződés következménye, melyben rögzítve lett, hogy az önkormányzati fenntartók által biztosított iskolaműködtetési támogatások átlagát kapják meg az államtól az egyházi intézmények.

6 Elsősorban médiahírekben olvashatók összehasonlító elemzések a tandíjakról. 2019-ben havi 75-100 ezer Ft jellemző, a Waldorf-iskolákban ennek csak harmada-fele, a nemzetközi iskolákban pedig akár egy nagyságrenddel is nagyobb összeg. Az állam által biztosított egyházi kiegészítő támogatáshoz képest még az alacsonyabb költségtérítési összegek éves bevétele is jelentősen nagyobb egy magániskolában. 
élvező magániskolák eldönthetik, hogy igénybe veszik-e támogatást, vagy más forrásból fedezik a tankönyigényeket.

A magániskolák - saját forrásaik szükségszerü bővítése miatt - hagyományosan élen jártak a különböző pályázati források megszerzésében, mely 2014-ig (amikortól az intézményi pályáztatás helyett jellemzővé vált az uniós fejlesztési támogatások kiemelt projektekbe való szervezése) komoly alternatív forrást jelentett számukra, növelve ezzel e szektor innovációs potenciálját.

Fentieket összefoglalva, a közoktatás területén müködő magánintézmények finanszírozása lényegében változatlan a rendszerváltás óta, a központi források ingadozása inkább a gazdaság helyzetével függött össze, és hasonlóan alakult, mint az állami vagy önkormányzati iskoláknál.

\section{A magániskolák ellenőrzése}

A források felhasználásának ellenőrzési rendszere, ahogyan a tanügyigazgatási megfelelés is, azonos a többi szektor elöírásaival. Elmondható, hogy már az iskolaalapításkor is elsősorban az adminisztratív megfelelést ellenőrzik, föleg az infrastruktúra terén. Ugyan a tanügyigazgatási dokumentumokra tartalmilag is szigorú törvényi elöírások vonatkoznak, a magániskolák maguk alakíthatják ki saját szervezeti működésüket, és a kapcsolódó dokumentumaik annak megfelelően kell, hogy elkészüljenek. A másfajta logika esetenként róhat többletterhet ezekre az intézményekre, de lényegében a megkövetelt adminisztráció és azok ellenőrzése is azonos módon történik más iskolákéval.

$\mathrm{A} z$ elmúlt tíz évben érzékelhetően erősödött a központi statisztikai adatgyűjtéshez kapcsolt ellenőrzési rendszer, mely a korábbihoz képest pontosabb adminisztrációt igényel. Ma már a hivatalok is fejlett informatikai rendszereket müködtetnek, melyeken keresztül gyakrabban válnak láthatóvá hibák is. A szektor képviselőinek elmondása szerint a köznevelés magániskolái felkészültek az ellenőrzésekre, a hatóságok esetében sem jellemző ellenséges hozzáállás, inkább előfordul az alternatív képzés sajátosságaira vontakozó tudáshiány, melyből adódóan a felek nem mindig beszélik egymás nyelvét. Ennek áthidalására pl. a pedagógusok minősítési rendszeréhez kidolgozott útmutatók között már megtalálható egy kifejezetten az alternatív kerettantervek szerint mủködő intézményekhez készült kiegészítés is, melyek kidolgozásába a magánszektor képviselöi is be lettek vonva.

\section{A magán szakképző intézmények leépítése}

Az ezredfordulóra a szak- és felnőttképzés területén is kedvezően alakult a magánintézmények finanszírozása. A kilencvenes évek végére a gazdasági szerkezetváltás és számos nagyipari vállalat bezárása nyomán korábban nem látott méretet öltött az ifjúsági munkanélküliség, melynek megoldását a fiatalok oktatásba terelésében látta az akkori kormányzat. Részben ennek a következménye 1996-ban a tankötelezettség 18 évre emelése, a szak- és felnőttképzésben pedig elindítója az államilag támogatott, de piaci szereplőként jelen lévő képzőintézetek megerősödésének. A szakképzés nagyvállalati hátterének összeomlása miatt az új igényekre az állami szakképzés nem tudott kellő rugalmassággal reagálni, ezért az állami feladatellátásba olyan piaci szereplők is becsatlakoztak, amelyek képesek voltak rugalmasan reagálni a munkaerőpiaci és lakos- 
sági igényekre, az állam pedig kedvező feltételek mellett támogatta a többnyire a felnőttképzésből érkező intézményeket. 2000 után, a növekvő keresletre reagálva kölönösen jelentős lett a magániskolák szerepe az érettségi utáni szakképzésben. Tomasz Gábor számításai szerint (Balázs-Kocsis-Vágó 2011: 5.17. táblázat) 2009-ben az érettségire épülő szakképzésben 84470 tanuló vett részt, ezek 2,5\%-a járt egyházi, 45,1\%-uk pedig magánfenntartású intézménybe. 2010-ig egyenletes növekedés volt jellemző ezen a területen.

A legtöbb magán szakképző iskola szorosan együttműködött az önkormányzati fenntartású intézményekkel, gyakorta tőlük bérelték a tantermeket, a tanárok egy része mindkét intézménytípusban oktatott. Az uniós csatlakozás után további források kerültek a rendszerbe, többnyire a munkaügyi központokon keresztül, melyek segítették néhány nagyobb képzőintézmény megerősödését is. A jól prosperáló iskolákban a jellemző képzési területek a piacképes végzettséget biztosító, többnyire kis befektetési igényű szakmák voltak: informatika, vendéglátóipar, turisztika, kereskedelem.

A korábbi ábrákból is jól látható, hogy a magánintézmények esetében a szakképzési fókusz visszaszorult, de az okok a korábban ismertetett jogszabályi keretekből nem értelmezhetők. Ez ugyanis a 2012-től teljes újrastrukturáláson átesett szakképzési rendszer szakmaszerkezeti döntéseihez köthető, melynek során a magánintézmények aránya a szakképzésben negyedére-ötödére esett vissza, az érettségire épülő szakképzések esetében pedig szinte teljes leépítés történt (lásd: 5. ábra).

$\mathrm{A} z$ Educatio folyóirat jelen számának egyik tanulmánya részletesen elemzi a szakképzési átalakításokat, ezért itt csak a magánszakképzés visszaszorítását célzó szabályozási háttér kerül összefoglalásra. A megyék hosszú és rövid távú szakképzésfejlesztési koncepciójának kidolgozása 2015 óta a Megyei Fejlesztési Képzési Bizottságok (MFKB) feladata lett, ezek tehetnek javaslatot az ösztöndíjra jogosító szakképesítésekre, a hiányszakmákra és a megyei fenntartók által indítandó szakképesítések keretszámaira. Ez utóbbit a szakmaszerkezeti döntéseket rögzítő kormányrendeletben teszik közzé,

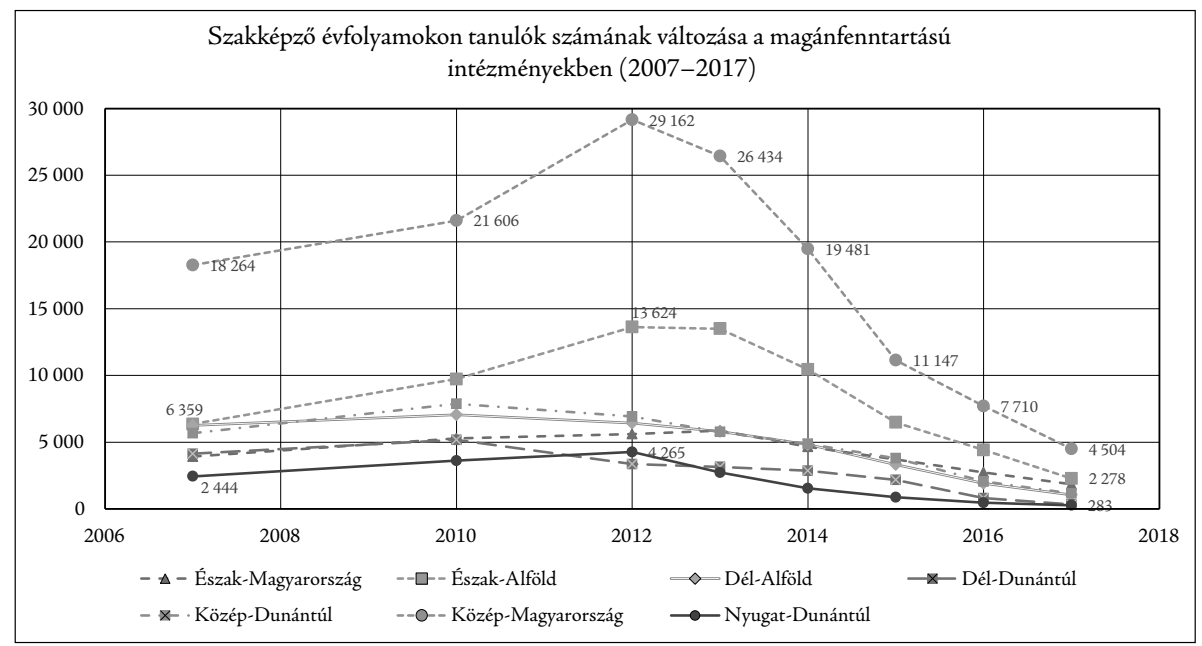

5. ábra: A szakképző évfolyamokon tanulók számának változása a magánfenntartású intézményekben, 2007-2017. Forrás: EDUMAP, 2017 (saját szerkesztés) 
melyben megyénként és fenntartónként elérhetők a támogatott és korlátozottan támogatott (azaz költségvetési hozzájárulásra jogosító) szakmai képzések keretszámai. A szakma képviselői egyöntetűen azon a véleményen vannak, hogy a képzési kínálatot és ezzel együtt a képzőintézmények tevékenységét rendkívüli módon behatároló keretszámok mögötti döntések szakmailag nem megalapozottak, érdemben nem készültek el a megyei szükségletelemzések, ezzel szemben a szakképzési centrumok által ad hoc módon bemondott igények köszönnek vissza a keretszámokban.

A támogatott szakmák körébe a relatíve alacsony tanulói, de magas munkaerőpiaci kereslettel jellemezhető szakmákat sorolták, így kiszorult ebből a körből az informatika, a kereskedelem, a közlekedés, szállítmányozás és logisztika, a turisztika és a vendéglátóipar is. Ezek a szakmák jelenleg egyetlen megyében sem tartoznak a támogatott ágazatok közé, vagyis csak a központilag meghatározott keretszámok erejéig indíthatják a kedvezményezett fenntartók. A megyék nagyjából felében viszont támogatottnak minősül a villamosipar és elektronika, a vegyészet, a gépészet, az egészségügy és az építőipar.

A szakmaszerkezeti döntésekben meghatározott keretszám adminisztratív eszköz lett a döntéshozók kezében az alapítványi és magán szakképző iskolák kiszorítására, ezzel együtt a szakképzésben korábban alig jelen lévő egyházi intézmények pozitív diszkriminációjára. Ugyanakkor a keretszámok több ágazati területen is felülmúlják a centrumok által lekötni képes kapacitásokat, s még inkább a végzettséget szerzők kibocsátását. Az 1. táblázat még a kifutó rendszerben müködő intézményeket is tartalmazza, de a szakmaszerkezeti döntések keretszámai alapján egyre kevesebb magánintézmény indíthat újként támogatott képzést.

1. táblázat: A különböző fenntartótípusokhoz tartozó szakképző iskolák aránya, 2018-2019.

\begin{tabular}{lc}
\hline Fenntartó típusa (számuk) & Iskolák aránya (\%) \\
\hline Magánfenntartó (37) & 12,0 \\
Felsőoktatási intézmény (5) & 0,7 \\
Állami szervezet (2: ITM, AM) & 67,3 \\
Tankerületi központ (22) & 7,6 \\
Egyházi jogi személy (46) & 12,3 \\
Nemzetiségi önkormányzat (2) & 0,2 \\
\hline
\end{tabular}

Forrás: KIR Intezmenyek 2019.03.11 szakképzés szakmacsoportok,

Oktatási Hivatal (saját szerkesztés)

\footnotetext{
Budapesten például a 2018-19-es tanévre előirányzott kb. 55000 férőhely 85\%-a az ITM fenntartása alá tartozó intézményekhez, 1\%-uk tankerületi központokhoz, 10\%-uk 12 különböző egyházi jogi személyhez, 1-1\%-uk 2 művészeti felsőoktatási intézményhez, illetve a Fővárosi Roma Nemzetiségi Önkormányzathoz tartozik. Ezzel szemben - a korábbi 30\%-nál magasabb arányukhoz képest - csak a finanszírozott helyek 3\%-a jut a 18 versenyben maradt magánszakképzőnek. Érdemes megnézni az állami keretszámok alakulását képzési ágazatonként is. A példaként vizsgált 12 informatikai szakmában $40 \%$-kal csökkentek a helyek az állami fenntartású intézményekben is, ami elörevetíthet egy következő szcenáriót, mely szerint bizonyos szakmákat érdemesebb átterelni a rövid ciklusú felsőoktatásba és a fizetőképes keresletet megszólítani képes felnőttképzésbe. Ez kedvező hatású lehet bizonyos statisztikai mutatókra, lehetőséget ad a forráskivonásra, valamint a felnőttképzési piac bővítésére is.
} 
A magán szakképző intézmények az érettségire épülő szakképzés terén azokban a szakmákban voltak népszerüek, melyek munkaerőpiaci kereslete magas volt: egészségügy, építészet, informatika, közgazdaság, művészet, közművelődés, kommunikáció, ügyvitel, vendéglátás-turisztika. Az Alapítványi- és Magániskolák Egyesülete (AME) minden érdekképviseleti lehetőségével élve több fórumon is jelezte, hogy tagiskolái számára egyenlőtlen feltételeket teremt az új szabályozás. Honlapjukon jól követhető módon olvasható a több körös, két éven át tartó, ám eredménytelen tiltakozás. Kritikai érveik között szerepel, hogy a szakmaszerkezeti döntések a gazdaság igényeitől eltérítő, bürokratikus és drága képzési rendszert alakítanak ki; az évente változó keretszámok ellehetetlenítik a szakképzési rendszer fejlesztését, a közép és hosszú távú tervezést; valamint sérti a köznevelési törvényben biztosított többszektorú köznevelési rendszer elvet. A felnőttoktatás vonatkozásában pedig a 2011-es szakképzési törvényt módosító javaslat kapcsán jelzik, hogy az sérti a szektorsemlegességet és a szabad iskolaválasztás jogát is (AME 2015).

Az akkor még a Nemzetgazdasági Minisztériumhoz (NGM) benyújtott állásfoglalásokra egyértelmű válaszok születettek államtitkári aláírással:

- „(...) a (szak)képzés megvalósitása alapvetően az állam feladata és felelössége, a nem állami fenntartású szakképzö intézmények állami támogatására csupán abban az esetben van lebetöség, ha az iskola által nyújtani kívánt képzések biánypótló szereppel bírnak, azaz ha a térségben felmerülö képzési igényeket az állami fenntartású szakképzö intézmények nem tudják lefedni." (NGM, 2016. október)

- „Az állami támogatás igénybevétele nélkül történő beiskolázást a jogszabály nem korlátozza, ezért amennyiben magánfenntartásban lévő szakképzö iskolák belyzetüket tovább szeretnék stabilizálni, javasoljuk számukra azon képzések inditását, amelyek a szakmaszerkezeti döntésekben korlátlanul támogatottak.

Azokat a szakmailag jól müködö magánfenntartású intézményeket, amelyek a fenti lehetőségek ellenére sem érzik biztosnak müködésüket, a szakképzési szakterület, az elmúlt idöszakhoz hasonlóan tovább ösztönzi, hogy csatlakozzanak önkéntesen az állami fenntartású szakképzési centrumokhoz mint teljes jogú tagintézmények." (NGM, 2017. május)

Az AME szerette volna elérni, hogy az NGM dolgozza ki a magán szakképzési centrumok létrehozásának jogszabályi feltételeit, illetve jogszabályban rendezze a szakképzésben önfinanszírozással tanulni kívánók státuszát. Az állami szakképzési centrumokkal való társulási szerződések feltételei a szektor képviselője szerint elfogadhatatlanok voltak (pl. teljes vagyonkezelési jog átruházása).

2019 márciusában jelentette be a kormányzat a Szakképzés 4.0 stratégiát, mely a 2020tól induló újabb átalakításokat összegzi egy jövőoritentált stratégiai dokumentumban. Az ITM miniszteri sajtótájékoztatója szerint az iparkamarák és a vállalatok kezdeményezésére fejlesztik tovább a szakgimnáziumokat technikumokká, sok szakma kikerül majd a felnőttképzésbe vagy megszünik; a szakmai tantárgyak oktatása során meg kell jelennie a digitalizációnak stb. Megváltozik a szakképzési irányok meghatározásának módszere is, vagyis a szakmaszerkezeti döntés keretszámai helyett hároméves együttműködési megállapodásokat fognak kötni a nem állami fenntartókkal a munkaerőpiaci előrejelző rendszer alapján, melyeket az MFKB-k helyett a megyei foglalkoztatási paktumok támogatnak, iskolai vonatkozásokban pedig kancellárok döntenek. A dokumentum expliciten kimondja, hogy meghatározó és az is marad az állami fenn- 
tartás, az egyházak elsősorban a humán és a szociális ágazatokban, illetve a hátrányos helyzetüek képzésében kell, hogy nagyobb szerepet kapjanak és speciális esetekben van csak szükség az alapítványi iskolákra is. „A gazdaság középtávú szakember-utánpótlását az állami szakképzö intézményekre kell alapozni." (Szakképzés 4.0)

A szakiskolai és készségfejlesztő iskolai programok esetén az új szakképzési koncepció egyértelműsíti, hogy az intézménytípus inkább a közneveléshez kötődik, ezért erre az intézménytípusra vonatkozóan nem fogalmaz meg terveket.

Annak hatása, hogy a nem állami fenntartású szakképző intézmények vonatkozásában nem tudott létrejönni olyan kölcsönösen elfogadható megállapodás, mely akár az új struktúrán belül teremti meg továbbmüködésük feltételeit, bizonytalan időre vetheti vissza a jó minőségű szakmai oktatást sok területen. Emellett további veszteséget jelent ezeknek az intézményeknek a szervezési és felnőttképzési tudása és a humánerőforrás kilépése az oktatási ágazatból (nyugdíjba vonulás vagy visszatérés a szakmába). Sok magániskola a módosítások következtében és a túlélés érdekében többszöri fenntartóváltáson esett át az elmúlt években. Az átrendeződések és megszünések belső mozgatórugóit érdemes volna esettanulmányok formájában feltárni. Vélhetően számos korábban magánintézményként működő iskola csak egyházi fenntartásba vétellel tudott megmaradni, így a szakképzés arányának növekedése az egyházi intézményeken belül részben ezzel is magyarázható.

\section{Összegzés és konklúzió}

A 2010 után erős politikai akarattal végigvitt, az oktatás egészére nézve rendszerszintű változtatási folyamatok kommunikált szándéka és társadalmi célja az esélyegyenlőség növelése és a minőségjavítás fókuszba helyezése volt, ugyanakkor nem világos, hogy mitől várható a rendszerben javulás. A több évtizede tudható demográfiai kihívások kezelésére egyetlen kormányzat sem készített koncepciót, a szétaprózott önkormányzati rendszerben - részben a gyerekszám drasztikus csökkenése miatt - finanszírozhatatlanná vált a kisiskolák fenntartása, a hátrányok egyre növekedtek a leszakadó régiókban, a rendkívül szelektívvé vált oktatási rendszerben erős szegregáció jellemző, az alapkészségek fejlesztése terén pedig egyértelmű hiányosságot mutatnak az országos és nemzetközi mérések. Ezeknek a problémáknak a megoldását a teljes szakma régóta sürgette, ezért elvitathatatlan, hogy az oktatási rendszer diszfunkciói beavatkozást igényeltek. $\mathrm{A} z$ iskolák két ütemben véglegesített állami fenntartó alá vonása, az egységes tankönyvek bevezetése és a merevebb tartalmi szabályozás azonban nehezen értelmezhető válasz egy modern szakpolitikaalkotási perspektívából. Véleményem szerint a kilencvenes évek lezáratlan oktatásszociológiai vitái, amelyek más formában éledtek újra a kétezres évek kompetencia vs. ismeret diszkussziójában, valamint a 2010 utáni leegyszerűsítő politikai válasz együttesen komoly tünetei annak, hogy a rendszerváltás óta eltelt harminc év nem volt elég ahhoz, hogy az oktatásról való gondolkodásban társadalmi normaként jelenjen meg a sokszínüség, értékteremtő lehetőségként az iskolai autonómia, és elfogadott szakmai tényként a komplexitás, melyben a merev struktúrák múködésképtelenek, ellenben fontos szerepük van a tanulási hálózatoknak, a szakpolitikai kísérletezésnek, és a direkt és indirekt irányítási mechanizmusoknak a soktényezős, sokszintű és sokszereplős ökoszisztémában. 
A 2011-es köznevelési törvény az iskolák államosításának keretében - az óvodák fenntartását kivéve - kizárta az önkormányzatokat a közoktatási intézmények lehetséges fenntartói közül és állami fenntartásba helyezte át az iskolákat. Ez a rendszerváltás óta történt legerőteljesebb törvényi beavatkozás volt az oktatási rendszerbe, de a változások lényegében nem érintették közvetlenül a magániskolákat. A szakmaszerkezeti döntésekre vonatkozó kormányrendeletek azonban egyértelműen negatív diszkriminációt jelentenek a magán szakképző intézmények vonatkozásában. A mögöttes ok vélhetően a közoktatásban harminc év alatt - nem kis mértékben kormányzati támogatással - felfejlődött piaci mechanizmusok visszaszorítása. Noha a jogi korlátozás explicit módon nem korlátozó a piaci szereplőkre nézve, a versenyfeltételek nyilvánvalóan egyenlőtlenek. A már kiépült, jól működő szolgáltatások leépítése pedig súlyos tudásbeli veszteséggel jár.

A kilencvenes évek végére a centralizált és átpolitizált közigazgatás lebontása és a decentralizált önkormányzati rendszer kiépítése együtt járt az új hatalmi pozíciók megszerzésére irányuló törekvésekkel és a különböző érdekcsoportok helyi szintű vagy szervezeti vetélkedésével, melybe a pártpolitikai nézetrendszerek különbözősége is beleszólt. A kilencvenes években a tanszabadság egyfajta idealizált értelmezése nyert teret, amelyben az iskolák meglehetősen nagy autonómiát élvezhettek. Fenntartóik legnagyobb arányban az önkormányzatok lettek, az állam a tartalmi szabályozáson keresztül ugyan közvetlenül is befolyást gyakorolt az oktatás egészére, de nem épültek ki a megfelelő kontrollmechanizmusok (Kozma 2012). Az oktatáskutatás, oktatásszociológia, neveléstudomány - mint az oktatási szakpolitikákat támogató szakmai bázis - együtt fejlődött az újként kiépülő folyamatokkal. A rendszerváltás utáni reformok jelentős strukturális változásokat hoztak, így a szakma fókusza is eleinte a strukturális kérdésekre irányult. Az oktatás minőségfejlesztését szolgáló irányítási mechanizmusok és ösztönző rendszerek központi kiépítése elmaradt, a minőségbiztosítás helyi szintre delegálódott. Arra vonatkozóan hogy miként lehetne kiépíteni egy fejlesztő jelleggel bíró elszámoltatási rendszert, a felszabadított közoktatási rendszer egészében harminc év alatt nem érlelődtek ki a szakmapolitikai válaszok. Ezért leginkább azok az iskolák voltak képesek fejlődni, amelyek rá voltak szorítva a versenyre, vagy részt vettek az ezredforduló körül induló nemzetközi know how-t behozó fejlesztési programokban, illetve olyan önvezérelt pedagógusok voltak az alapítói, akik a tanári hivatást a pedagógiai szabadság kiteljesedésével járó önmegvalósító lehetőségként élték meg, jelentős számban magániskolákat alapítva.

Ebben a megvilágításban tudományos szempontból is felértékelődnek a magániskolák, amelyek folyamatosan kísérleteznek, saját tanulási hálózatokat alapítottak, és mindeközben alkalmazkodtak minden lezajlott strukturális reformtörekvéshez és tanügyigazgatási változáshoz is. Az alternatív intézmények szereplöi ugyanakkor keveset publikálnak, ők „24 órában iskolát építenek”, ${ }^{8}$ így lényegében erős tudáshiány érzékelhető a működésükről a szakma egészében. Érdemes volna összevetni az ezekben az intézményekben elindult innovációkat az állami keretek között működő iskolákban tetten érhető fejlesztésekkel. Nagy valószínüséggel kimutatható volna, hogy a strukturális keretek e téren nem meghatározóak, az innovációt sokkal inkább a szervezeti kultúra határozza meg, mely fenntartótíputól függetlenül alakítható. Ilyen kutatások segíthetnének helyreállíthatani a szakpolitikai fejlesztések fókuszát is.

A mondatot az Alapítványi és Magániskolák Egyesületének egyik tagozatvezetője mondta a háttérinterjú során. 


\section{IRODALOM}

\section{Jogszabályok}

Alkotmány $(1989,2011)$

Egyházügyi törvény (2011) és 2013-as módosítása

Költségvetési törvény (2018)

Közoktatás és köznevelés törvények $(1985,1993,2011)$ és módosításaik, valamint kapcsolódó rendeletek

Szakkképzési törvény (2011)

Szakmaszerkezeti döntések (2015, 2016, 2017, 2018, 2019)

\section{Tudományos publikációk és szakmai háttéranyagok}

Alapítványi és Magániskolák Egyesülete honlap >> Szakképzési Tagozat (2015-ös NGM egyeztetés háttéranyagai és 2016-17-es levelezés a Nemzetgazdasági Minisztérium Szakképzésért és Felnőttképzésért Felelős Helyettes Államtitkárságával). http://ame.hu/ category/szakkepzesi-tagozat/ [Letöltve: 2019. 05. 11.]

Balázs É., Kocsis M. \& VÁGó I. (2011, eds) Jelentés a magyar közoktatásról 2010. Budapest, Oktatáskutató és Fejlesztő Intézet.

Dовоs O. (2017) Alternatív iskolák... Tani-tani online. http://www.tani-tani.info/alternativ_ iskolak [Letöltve: 2019. 05. 11.]

EAG (2018) OECD Education at a Glance 2018. OECD Indicators. Paris, OECD Publishing.

HalÁsz G. \& LANnert J. (2000, eds) Jelentés a magyar közoktatásról 2000. Budapest, Országos Közoktatási Intézet.

Knausz I. (2018) Társadalmi folyamatok és pedagógiai kultúra. Interjú Knausz Imrével. In: B. Tier N. \& Szegedi E. (eds) Alma a fán. Pedagógusok szerepe és szakmai fejlödése a 21. században. Budapest, Tempus Közalapítvány. p. 50 .

Kozma T. (2012) Oktatáspolitika. Debrecen-Pécs. http://mek.oszk. hu/11200/11203/11203.pdf [Letöltve: 2019. 05. 11.]

Szakképzés 4.0 (2019) Innovációs és Technológiai Minisztérium: Szakképzés 4.0 - A szakképzés és felnőttképzés megújításának középtávú szakmapolitikai stratégiája, a szakképzési rendszer válasza a negyedik ipari forradalom kihívásaira.

VÁGó I. (2005) Ki mit talált ki? Iskolakultúra, Vol. 15. No. 11. pp. 42-58. Budapest, Országos Közoktatási Intézet.

\section{Adatbázisok}

EDUMAP: http://edumap.ofi.hu/ [Letöltve: 2019. 07.31.]

EUROSTAT: https://ec.europa.eu/eurostat/web/education-and-training/data/database [Letöltve: 2019. 07. 31.]

KSH Stadat: https://www.ksh.hu/stadat [Letöltve: 2019. 07.31.]

A cikk a Creative Commons Attribution 4.0 International License (https://creativecommons.org/licenses/ by/4.0/) feltételei szerint publikált Open Access közlemény, melynek szellemében a cikk bármilyen médiumban szabadon felhasználható, megosztható és újraközölhető, feltéve, hogy az eredeti szerző és a közlés helye, illetve a CC License linkje és az esetlegesen végrehajtott módosítások feltüntetésre kerülnek. (SID_1) 